\title{
Hypophosphorylation of the architectural chromatin protein DEK in death-receptor-induced apoptosis revealed by the isotope coded protein label proteomic platform
}

\author{
Anja Tabbert ${ }^{1}$, Ferdinand Kappes ${ }^{2 *}$, Rolf Knippers ${ }^{2}$, Josef Kellermann ${ }^{3}$, \\ Friedrich Lottspeich ${ }^{3}$ and Elisa Ferrando-May ${ }^{1}$ \\ ${ }^{1}$ University of Konstanz, Molecular Toxicology Group, Konstanz, Germany \\ ${ }^{2}$ University of Konstanz, Laboratory of Molecular Genetics, Konstanz, Germany \\ ${ }^{3}$ Max Planck Institute of Biochemistry, Protein Analytics, Martinsried, Germany
}

\begin{abstract}
During apoptosis nuclear morphology changes dramatically due to alterations of chromatin architecture and cleavage of structural nuclear proteins. To characterize early events in apoptotic nuclear dismantling we have performed a proteomic study of apoptotic nuclei. To this end we have combined a cell-free apoptosis system with a proteomic platform based on the differential isotopic labeling of primary amines with $\mathrm{N}$-nicotinoyloxy-succinimide. We exploited the ability of this system to produce nuclei arrested at different stages of apoptosis to analyze proteome alterations which occur prior to or at a low level of caspase activation. We show that the majority of proteins affected at the onset of apoptosis are involved in chromatin architecture and RNA metabolism. Among them is DEK, an architectural chromatin protein which is linked to autoimmune disorders. The proteomic analysis points to the occurrence of multiple PTMs in early apoptotic nuclei. This is confirmed by showing that the level of phosphorylation of DEK is decreased following apoptosis induction. These results suggest the unexpected existence of an early crosstalk between cytoplasm and nucleus during apoptosis. They further establish a previously unrecognized link between DEK and cell death, which will prove useful in the elucidation of the physiological function of this protein.
\end{abstract}

Received: March 20, 2006

Revised: June 6, 2006

Accepted: June 23, 2006

\section{Keywords:}

Caspase / hnRNP / Isotope coded protein label / Oncoprotein / Post-translational modification

Correspondence: Dr. Elisa Ferrando-May, University of Konstanz, Molecular Toxicology Group, P.O. Box 911, D-78457 Konstanz, Germany

E-mail: elisa.may@uni-konstanz.de

Fax: +49-7531-884033

Abbreviations: CAD, caspase-activated DNase; CD95-L, CD95 ligand; DFF, DNA fragmentation factor; ICPL, isotope coded protein label

\section{Introduction}

The demolition of the nucleus during apoptosis proceeds in distinct steps and through different shapes beginning with a more or less pronounced peripheral chromatin margination,

* Current address: Department of Internal Medicine, Division of Infectious Diseases, University of Michigan, Ann Arbor, MI, USA 
often accompanied by disruption of the nucleolus, to a late morphology characterized by shrinkage, convolution of the nuclear envelope, and fragmentation into apoptotic bodies $[1,2]$. These structural changes are mainly the consequence of the proteolysis of nuclear proteins like lamins and Tpr, and of chromatin cleavage into high-molecular weight and oligonucleosomal fragments [3-6]. The major execution system involved in these processes is the caspase family of proteases [7]. These enzymes can directly cleave nuclear proteins and activate apopototic DNases like caspase-activated DNase (CAD)/DNA fragmentation factor (DFF40). In addition, several caspase-independent factors were shown to contribute to apoptotic nuclear alterations, including AIF [8], endonuclease G [9], DNaseII [10], phospholipase A2 [11], and Acinus [12].

Abnormalities in the packaging of nuclear constituents into apoptotic bodies and their subsequent clearance by phagocytosing cells may lead to the exposure of novel antigens and the initiation of an autoimmune response. Indeed, circulating antinuclear autoantibodies are a hallmark of many systemic autoimmune disorders [13, 14]. Apoptosisinduced PTMs of nuclear proteins may increment the immunogenicity of self-antigens [15]. Therefore, the study of apoptosis-induced structural and functional alterations of nuclear proteins is of crucial importance to understand the mechanisms regulating apoptotic nuclear dismantling and its connection to autoimmunity.

The technique of choice to achieve a comprehensive characterization of changes in the protein complement of the nucleus during apoptosis is subcellular proteomics [16]. This strategy usually consists of a combination of cell fractionation procedures and comparative proteomic analysis of the compartment of interest, in this case purified nuclei. The main advantage of this approach is the enrichment of lowabundance proteins which may remain undetected when total crude extract is employed as starting material, mainly due to the limited resolving capacity of 2-DE [17].

Subcellular proteomic studies of apoptosis are still sparse so far. Two groups have reported on the translocation of hnRNP proteins out of the nucleus during cell death $[18,19]$ and characterized apoptosis-induced alterations of the nuclear matrix [20]. They both employed the classical approach of comparative high-resolution 2-DE of nuclear fractions followed by the mass spectrometric analysis of interesting spots. The range of $\mathrm{p} I$ that was analyzed extended from approximately 5 to 9 in one case [18], and from 4 to 7.5 in another case [20]. However, a large number of nuclear proteins, in particular those directly binding to DNA, are positively charged and migrate at $\mathrm{p} I$ values $>10$. Such proteins are difficult to identify by conventional approaches due to the poor resolution and reproducibility of 2-Dgels in the basic region [21].

In this work we have employed an alternative strategy to perform a proteomic study of apoptotic nuclei. We exploited a recently developed technique of stable isotopic labeling of protein mixtures, termed ICPL (isotope coded protein label), which was successfully employed for the analysis of basic proteins [22]. Similarly to the isotope coded affinity tag (ICAT) platform pioneered by Aebersold and coworkers [23], the protein samples to be compared are chemically derivatized with two distinguishable isotopic forms (light, nondeuterated, $\mathrm{d}_{0}$ and heavy, deuterated, $\mathrm{d}_{4}$ ) of the ICPL reagent, $N$-nicotinoyloxy-succinimide [22]. The differentially labeled samples are subsequently combined and separated by high-resolution 2-DE. Here, proteins labeled with isotopically different forms of the ICPL reagent coseparate and are recovered from the same spot. Changes in protein abundances are then accurately determined by comparing the ratio of the mass spectrometric signal intensities of the heavy and light forms of the labeled peptides. Differently from the ICAT reagent, which labels cysteines, the ICPL reagent quantitatively modifies primary amino groups. This reduces the $\mathrm{p} I$ of the labeled proteins and shifts the position of the corresponding spots in 2-DE to the acidic side. The magnitude of the shift is proportional to the number of basic amino groups present. Highly basic proteins, such as nuclear proteins, can thus be separated in the neutral to acidic region of the gels, where resolution is not a problem [22].

Cell-free apoptosis systems have been instrumental to the identification of many factors involved in apoptotic nuclear execution [24]. Typically, these systems consist of nuclei purified from healthy cells or tissues and cytosolic extracts derived from cells stimulated to undergo apoptosis [25-27]. One advantage of this approach is that apoptotic alterations are induced in all nuclei independently of the variable responsiveness of individual cells to the apoptotic trigger. The stage of apoptosis reached in these nuclei depends on the time point at which the cells are harvested for extract isolation after apoptosis induction. The process of nuclear destruction can thus be temporally dissected. In particular, this method allows for the study of early apoptotic events which are difficult to observe in a cell population due to the asynchronous onset of the apoptotic process.

Goal of this study was the identification of early alterations of the nuclear proteome, which may occur prior, or at the beginning of the caspase cascade. To this end we have exploited cell-free apoptosis as a technique to generate early apoptotic nuclei and performed a comparative proteomic study using the ICPL platform.

Our results show that already prior to detectable alterations of chromatin structure and preceding the full activation of executioner caspases a number of nuclear proteins are altered in death receptor-induced cell death. The majority of the identified proteins participate in chromatin function and RNA metabolism. Among them is DEK, an architectural chromatin factor that has been implicated in the pathogenesis of cancer and autoimmune disorders [28, 29]. The involvement of DNA and RNA-binding factors in the early phase of apoptosis is a previously unrecognized aspect of the receptor mediated death pathway. 


\section{Materials and methods}

\subsection{Cell culture, apoptosis induction, and measurement of caspase activity}

Jurkat T-cells (Clone E6-1) were grown in RPMI 1640 medium containing $5 \% \mathrm{FCS}$ at $37^{\circ} \mathrm{C}$ in a humidified atmosphere. For induction of apoptosis cells were incubated in serum-free medium at a density of $5 \times 10^{6}$ cells $/ \mathrm{mL}$ with $2.5 \%$ CD95 ligand (CD95-L)-containing culture supernatant from CD95L-expressing N2A cells [30]. Apoptosis in the culture was monitored at regular intervals by staining aliquots of the cells with a combination of the fluorescent chromatin dyes Hoechst $33342(500 \mathrm{ng} / \mathrm{mL})$ and Sytox $(500 \mu \mathrm{M})$. Cells impermeable to Sytox and with condensed or fragmented nuclei were scored as apoptotic.

Caspase activity was determined essentially as described previously [4]. Briefly, cells were lysed in $25 \mathrm{mM}$ HEPES $\mathrm{pH}$ 7.5, $5 \mathrm{mM} \mathrm{MgCl}_{2}, 1 \mathrm{mM}$ EGTA, 0.5\% Triton X-100 and the cleavage of DEVD-afc $(40 \mu \mathrm{M})$ was monitored fluorimetrically in reaction buffer $(50 \mathrm{mM}$ HEPES pH 7.5, $10 \mathrm{mM}$ DTT, $1 \%$ sucrose, $0.1 \%$ CHAPS) over a period of $20 \mathrm{~min}$ at $37^{\circ} \mathrm{C}$ with $\lambda \mathrm{ex}=390 \mathrm{~nm}$ and $\lambda \mathrm{em}=505 \mathrm{~nm}$. The activity was calibrated using afc standard solutions. Measurements were run in triplicate.

\subsection{Isolation of cytosolic extracts}

Cells were harvested by centrifugation at $4^{\circ} \mathrm{C}$, washed twice carefully in ice-cold PBS and once in transport buffer (20 mM HEPES, pH 7.3, $110 \mathrm{mM}$ potassium acetate, $5 \mathrm{mM}$ sodium acetate, $2 \mathrm{mM}$ magnesium acetate, $0.5 \mathrm{M}$ EGTA, $250 \mathrm{mM}$ sucrose) supplemented with protease inhibitors and $1 \mathrm{mM}$ DTT. After addition of an amount of transport buffer corresponding to the same volume of the packed cell pellet containing $2.4 \mathrm{mg} / \mathrm{mL}$ digitonin (equivalent to $60 \mu \mathrm{g}$ digito$\operatorname{nin} / 5 \times 10^{7}$ cells) the cells were lysed for $10 \mathrm{~s}$ under vigorous stirring, followed by incubation on ice for $3 \mathrm{~min}$. Organelles and cell debris were removed by centrifugation at $18000 \times \mathrm{g}$ for $15 \mathrm{~min}$ at $4^{\circ} \mathrm{C}$. The supernatant was snap frozen and stored at $-80^{\circ} \mathrm{C}$.

\subsection{Isolation of mouse liver nuclei}

Isolation of nuclei was performed according to the protocol of Blobel and Potter [31] with modifications introduced by Cordes [32]. All separation steps were performed at $4^{\circ} \mathrm{C}$. All buffers were supplemented with $1 \mathrm{mM}$ DTT and $30 \mu \mathrm{g} / \mathrm{mL}$ trypsin-inhibitor immediately before usage. Liver tissue of 2$30 \mathrm{~g}$ from $\mathrm{C} 3 \mathrm{HeB} / \mathrm{Fe}$ ) mice were homogenized in $50-100 \mathrm{~mL}$ of ice-cold buffer A (15\% sucrose, $1 \mathrm{mM}$ Tris/ $\mathrm{HCl} \mathrm{pH} \mathrm{7.2,}$ $70 \mathrm{mM} \mathrm{KCl}, 2 \mathrm{mM} \mathrm{MgCl}_{2}$ ). The homogenate was filtered through gaze and centrifuged for $10 \mathrm{~min}$ at $4^{\circ} \mathrm{C}$ and $1000 \times \mathrm{g}$. The pellet was resuspended in buffer $\mathrm{A}$ and mixed with a $92 \%$ sucrose solution in $10 \mathrm{mM}$ Tris/ $\mathrm{HCl} \mathrm{pH} 7.2$ and $2 \mathrm{mM}$ $\mathrm{MgCl}_{2}$ to yield a $70 \%$ sucrose suspension that was finally transferred on top of $72 \%$ sucrose cushions. Nuclei were separated by centrifugation for $60 \mathrm{~min}$ at $4^{\circ} \mathrm{C}$ and $40000 \times \mathrm{g}$. The pelleted nuclei were resuspended in an adequate volume of buffer $\mathrm{A}$, dounced and centrifuged again for $10 \mathrm{~min}$ at $4^{\circ} \mathrm{C}$ and $1000 \times$ g. Nuclei were stored at $-80^{\circ} \mathrm{C}$ in buffer A supplemented with $20 \%$ glycerol.

\subsection{Cell-free apoptosis reaction}

Purified mouse liver nuclei $\left(1 \times 10^{8}\right)$ were incubated with a volume of cytosolic extract corresponding to $4 \mathrm{mg}$ of total protein in extract dilution buffer $(10 \mathrm{mM}$ HEPES pH 7.0, $50 \mathrm{mM} \mathrm{NaCl}, 2 \mathrm{mM} \mathrm{MgCl}$, $5 \mathrm{mM}$ EGTA) in a total volume of $600 \mu \mathrm{L}$. The reactions were supplemented with an ATP regenerating system $(10 \mathrm{mM}$ phosphocreatine, $2 \mathrm{mM}$ ATP, $1 \mathrm{mM}$ DTT, and 15-20 mU/mg creatine phosphokinase) and incubated at $37^{\circ} \mathrm{C}$ under moderate shaking $(300 \times \mathrm{rpm})$ for $10 \mathrm{~min}$. The nuclei were then recovered from the reaction mixture by centrifugation through a small sucrose step gradient consisting of 40 and $15 \%$ sucrose cushions $(500 \mu \mathrm{L}$ each) in $10 \mathrm{mM}$ Tris $/ \mathrm{HCl} \mathrm{pH} 7.2$ for $2 \mathrm{~min}$ at $4^{\circ} \mathrm{C}$ and $10000 \times \mathrm{g}$.

\subsection{Preparation of samples for immunoblot analysis}

For the preparation of whole cell extracts, Jurkat cells were harvested by centrifugation, washed in ice-cold PBS, resuspended in $95^{\circ} \mathrm{C}$ lysis buffer $(50 \mathrm{mM}$ Tris $/ \mathrm{HCl} \mathrm{pH} 8.0,0.5 \%$ SDS, $1 \mathrm{mM} \mathrm{DTT}$ ), and heated at $95^{\circ} \mathrm{C}$ for $10 \mathrm{~min}$. Cell debris was removed by centrifugation at $20000 \times \mathrm{g}$ for $10 \mathrm{~min}$.

Extracts for the analysis of cytochrome $c$ release from mitochondria were prepared by selective digitonin permeabilization of the plasma membrane as described by Single et al. [33]. Briefly, $4 \times 10^{6}$ cells were harvested and resuspended in $250 \mu \mathrm{L}$ PBS. Plasma membrane lysis was performed by adding $250 \mu \mathrm{L}$ of digitonin solution $(130 \mu \mathrm{g} / \mathrm{mL}$ in $500 \mathrm{mM}$ sucrose) to the cell suspension under vigorous stirring on a vortex for $10 \mathrm{~s}$ and further incubation at RT for $30 \mathrm{~s}$. The cytosolic fraction was quickly isolated by centrifugation for $60 \mathrm{~s}$ at $14000 \times \mathrm{g}$ and $4^{\circ} \mathrm{C}$. Proteins in the supernatant were precipitated with $5 \%$ TCA at $-20^{\circ} \mathrm{C}$ overnight.

For the analysis of nuclear proteins, nuclei recovered from the cell-free reaction (see above) were lysed in $95^{\circ} \mathrm{C}$ lysis buffer (50 mM Tris/HCl pH 8.0. 0.5\% SDS, 1 mM DTT).

\subsection{Antibodies and immunoblot analysis}

Whole cell extracts were employed for the detection of caspase- 8 and caspase- 3 processing, and Bid cleavage. Mitochondrial cytochrome $c$ release was analyzed in digitonin lysates, and cleavage of PARP-1 and lamin B in nuclear extracts.

Proteins were separated by SDS-PAGE according to Laemmli [34], transferred to NC membranes (Amersham Pharmacia Biotech, Uppsala, Sweden), blocked with 5\% nonfat dried milk in TBST $(50 \mathrm{mM}$ Tris $/ \mathrm{HCl} \mathrm{pH}$ 8.0, 0.05\% 
Tween 20, $150 \mathrm{mM} \mathrm{NaCl}$ ) for $1 \mathrm{~h}$ at RT and incubated with primary antibodies specific for caspase- 8 and caspase- 3 (Cell Signaling Technology, Danvers, MA, USA), cytochrome $c$ (Becton Dickinson Biosciences, Franklin Lakes, NJ, USA), Bid (Biosource International, Camarillo, CA, USA), lamin B (Santa Cruz Biotechnology, Santa Cruz, CA, USA), and PARP-1 (clone CII-10, kind gift of A. Buerkle) diluted in TBST containing 5\% nonfat dry milk for $1 \mathrm{~h}$ at RT. Filter washings were in TBST alone. Incubations with HRP-coupled secondary antibodies were in TBST-milk at room temperature for $1 \mathrm{~h}$. The Super Signal Western blotting detection system (Pierce Biotechnology, Rockford, IL, USA) was used according to the manufacturer's instructions.

\subsection{DNA fragmentation assay}

Nuclei recovered from the cell-free apoptosis reaction (3$\left.5 \times 10^{5}\right)$ were dissolved in $200 \mu \mathrm{L}$ DNA lysis buffer $(100 \mathrm{mM}$ Tris/ $\mathrm{HCl} \mathrm{pH} 8.5,5 \mathrm{mM}$ EDTA, 0.2\% SDS, $200 \mathrm{mM} \mathrm{NaCl}$ ) and incubated for $4 \mathrm{~h}$ at $37^{\circ} \mathrm{C}$ with $100 \mu \mathrm{g} / \mathrm{mL}$ proteinase $\mathrm{K}$. After separation of insoluble material, the DNA was recovered from the supernatant by isopropanol precipitation, resuspended in TE buffer and treated with $1 \mathrm{mg} / \mathrm{mL}$ RNase for $30 \mathrm{~min}$ at $37^{\circ} \mathrm{C}$. Oligonucleosomal DNA fragments were separated by conventional $1 \%$ agarose gel electrophoresis and visualized on a UV transilluminator after staining the gel with SybrGreen (Molecular Probes, Eugene, OR, USA) according to the manufacturer's instructions.

\subsection{ICPL reagent labeling and 2-DE}

An equal number of nuclei recovered from control and apoptotic cell-free reactions were dissolved in $6 \mathrm{M}$ guanidine $/ \mathrm{HCl} \mathrm{pH} 8.5$ by sonication and vigorous shaking. Insoluble material was removed by centrifugation. The supernatants were adjusted to the same protein concentration $(5 \mathrm{mg} / \mathrm{mL})$ and labeled with the $\mathrm{d}_{0^{-}}$(light, control) and $\mathrm{d}_{4^{-}}$ (heavy, apoptosis) substituted isoforms of $\mathrm{N}$-nicotinoylsuccinimide, respectively, as described in Schmidt et al. [22]. Equal aliquots of the two samples were mixed and dialyzed (cutoff $8 \mathrm{kDa}$ ) in a buffer containing $8 \mathrm{M}$ urea, $2 \mathrm{M}$ thiourea, 4\% CHAPS, and $40 \mathrm{mM}$ DTT. Carrier ampholytes pH 3-10 and Bromphenol blue were added to a final concentration of $2 \%(\mathrm{v} / \mathrm{v})$ and $0.0075 \%(\mathrm{w} / \mathrm{v})$. Samples were applied to IPG strips with a linear separation range of pH 3-6 (Amersham Biosciences). After overnight rehydration, IEF was carried out at $20^{\circ} \mathrm{C}$ and $80 \mathrm{kVh}$ in the following steps: $1 \mathrm{~h}$ at $300 \mathrm{~V}$ followed by a $300 \mathrm{~V}$ increase every $15 \mathrm{~min}$ to $5000 \mathrm{~V}$ and $15 \mathrm{~h}$ at $5000 \mathrm{~V}$. Strips were then soaked for $2 \times 10 \mathrm{~min}$ in a buffer containing $50 \mathrm{mM}$ Tris/ $\mathrm{HCl}, \mathrm{pH} 8.8,6 \mathrm{M}$ urea, 30\% w/v glycerol and 4\% w/v SDS and a trace of bromphenolblue. One percent w/v DTT was added to the first, $4 \%(\mathrm{w} / \mathrm{v})$ iodoacetamide was added to the second equilibration step. Second dimension electrophoresis was performed with an Ettan Dalt II system (Amersham Biosciences). IPG strips were placed on top of a $13 \%$ poly- acrylamide gel and electrophoresis was carried out at $20^{\circ} \mathrm{C}$ for $1 \mathrm{~h}$ at a constant current of $5 \mathrm{~mA}$ per gel. The current was then increased to $10 \mathrm{~mA}$ until the color front reached the lower end of the gel. Gels were silver-stained and scanned with a color image scanner (Sharp JX-330, Mahwah, NJ, USA). Protein spots were excised with an automatic cutter (BioRad, Munich, Germany) and enzymatically cleaved ingel with trypsin $(0.05 \mathrm{mg})$ overnight at $30^{\circ} \mathrm{C}$. Protein fragments were eluted with acidic and organic solvents and vacuum dried as previously described [22].

\subsection{MALDI-TOF/TOF analysis and data processing}

Eluted peptides were redissolved in $3 \mu \mathrm{L} 50 \% \mathrm{ACN}$ and $0.2 \%$ TFA. $0.4 \mu \mathrm{L}$ of this solution were mixed with the same volume of matrix solution (CHCA, $2.5 \mathrm{mg} / \mathrm{mL}$ ) on the MALDI target. Mass spectra were acquired with a Proteomics Analyzer 4700 (MALDI-TOF/TOF) mass spectrometer (Applied Biosystems, Forster City, CA, USA). Mass analysis was performed in the positive reflector mode with a deflection cut-off range corresponding to a mass/charge ratio of 800. A total of 2500 shots were carried out for both the MALDI-TOF and the MALDI-TOF/TOF experiments. To identify modified proteins, spectra were searched against the Swiss-Prot database using an in-house version of MASCOT [35]. Only those proteins were taken into further consideration that were identified on the basis of at least two different peptides within one single MS spectrum. Protein quantification was performed using the Peakpicker software (Applied Biosystems), which automatically calculates the relative abundance of light $\left(\mathrm{d}_{0}\right.$, control) and heavy $\left(\mathrm{d}_{4}\right.$, apoptotic) ICPL-labeled peptides as a ratio of light versus heavy. The $\mathrm{d}_{0}: \mathrm{d}_{4}$ ratios determined within one MS spectrum were averaged and the SD was calculated (see Supplementary Table 1 ). The $d_{0}: d_{4}$ ratio of a protein was considered significantly altered if the determined averaged value was greater than twice the SD.

\subsection{In vitro phosphorylation}

S-20 extracts were prepared from healthy Jurkat cells or Jurkat cells treated with CD95-L for the indicated time periods. Cells were resuspended in hypotonic buffer (10 mM HEPES, $\mathrm{pH} 7.5,5 \mathrm{mM} \mathrm{KCl}, 1.5 \mathrm{mM} \mathrm{MgCl}_{2}, 0.1 \mathrm{mM}$ DTT) supplemented with $250 \mathrm{mM}$ sucrose. After centrifugation $(164 \times \mathrm{g}$, $5 \mathrm{~min}, 4^{\circ} \mathrm{C}$ ) the cell pellet was redissolved in hypotonic buffer without sucrose, kept on ice for $30 \mathrm{~min}$ and Dounce homogenized to prepare the soluble cytoplasmic and nucleoplasmic proteins. The in vitro phosphorylation was carried out exactly as described in Kappes et al. [36].

\subsection{In vivo labeling with ${ }^{32} \mathrm{Pi}$}

Labeling of Jurkat cells with ${ }^{32} \mathrm{Pi}$ was performed by washing cells $\left(1 \times 10^{8}\right)$ three times with phosphate- and serum-free RPMI medium and then cultivating them in $2 \mathrm{~mL}$ of phos- 
phate- and serum-free medium supplemented with $200 \mu \mathrm{Ci}$ of ${ }^{32} \mathrm{Pi}$ (carrier free; ICN) for the indicated time points. For induction of apoptosis cells were treated with 2.5\% CD95-Lcontaining culture supernatant from CD95-L-expressing N2A cells [30] exactly as described above. Cells were harvested by centrifugation $(500 \times \mathrm{g}, 5 \mathrm{~min})$ and washed twice with ice-cold PBS, once with hypotonic buffer $(20 \mathrm{mM} \mathrm{NaCl}$, $20 \mathrm{mM}$ HEPES, pH 7.4, $5 \mathrm{mM} \mathrm{MgCl}_{2}$ ) followed by incubation in $2 \mathrm{~mL}$ hypotonic buffer supplemented with $0.5 \% \mathrm{NP}$ 40 and protease (Complete, Roche) and phosphatase inhibitors (NaF, Na-vanadate) for $15 \mathrm{~min}$ on ice. After adjusting the cell suspension to $450 \mathrm{mM} \mathrm{NaCl}$ and incubation for further $15 \mathrm{~min}$ on ice, insoluble material was pelleted $(1000 \times \mathrm{g}$, $10 \mathrm{~min}$ ) and the supernatant (whole cell lysate) was used for immunoprecipitation with DEK specific antibodies. Five micrograms of affinity purified polyclonal DEK antibody [36] were used for the equivalent of $1 \times 10^{6}$ cells. After $1 \mathrm{~h}$ incubation on ice, $30 \mu \mathrm{L}$ of a $50 \%$ protein A-Sepharose solution (Amersham Pharmacia) was added and the mixture was rolled at $4^{\circ} \mathrm{C}$ for another hour. The immunocomplexes were washed three times with $1 \mathrm{~mL}$ of extraction buffer $(450 \mathrm{mM}$ $\mathrm{NaCl}, 20 \mathrm{mM}$ HEPES, pH 7.4, $0.5 \mathrm{mM} \mathrm{MgCl}_{2}$ ) followed by dissociation from the beads with $2 \%$ SDS and $5 \% \beta$-mercaptoethanol at $37^{\circ} \mathrm{C}$ for $1 \mathrm{~h}$. The samples were separated by SDS-PAGE, blotted to NC and analyzed by autoradiography and immunoblotting.

\section{Results and discussion}

\subsection{A novel combination of cell-free apoptosis and proteomics}

The strategy employed here for the proteomic analysis of early apoptosis-induced nuclear alterations is outlined in Fig. 1. Apoptosis was induced in purified mouse liver nuclei by incubation with cytosolic extracts derived from CD95-L treated Jurkat cells. Control reactions were performed with extracts from untreated cells. Subsequently, the nuclei were recovered from the cell-free reactions and subjected to the ICPL proteomic platform [22].

The CD95-L triggered apoptotic pathway is very well characterized [37] and leukemia cells treated with CD95-L have been used as a source of cytosolic extracts for cell-free apoptosis reactions in the past (see e.g. [26, 27, 38]). To choose the time points of cell harvesting to isolate the extracts, we first analyzed known signal transduction steps triggered by CD95-L (Fig. 2). The results showed that initiator caspase-8, the most upstream caspase in this pathway, was already active at $40 \mathrm{~min}$ after treatment, as indicated by the appearance of the p18 active subunit in the corresponding immunoblot (Fig. 2A). Within $5 \mathrm{~min}$, caspase- 8 processing was followed by cleavage of $\mathrm{Bid}$, release of cytochrome $c$, and partial processing of caspase-3. Caspase 3/7-like activity (DEVDase) became detectable at $60 \mathrm{~min}$ after initial stimulation, followed by the condensation of chromatin at $90 \mathrm{~min}$

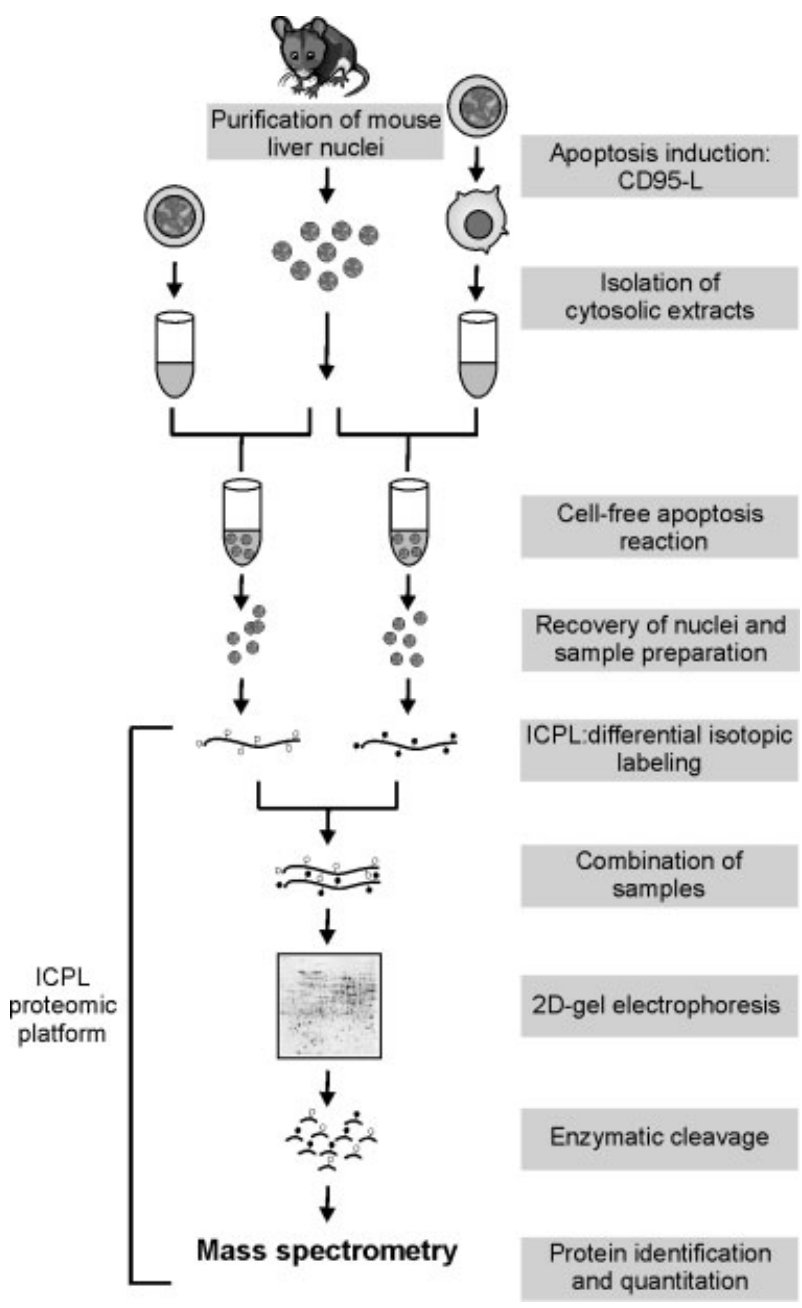

Figure 1. Strategy of the cell-free apoptosis/proteomic approach. Nuclear apoptosis was induced in vitro by combining nuclei isolated from mouse livers with cytosolic extracts derived from Jurkat cells stimulated with CD95-L. Control nuclei were incubated with extracts from untreated cells. The nuclei were recovered from the cell-free reactions by sedimentation through a small sucrose gradient and dissolved in a guanidine-containing buffer. The soluble material was subjected to differential labeling with the ICPL reagent: proteins of control nuclei were modified with the light, nondeuterated $(\mathrm{d} 0)$ form of the reagent, proteins of apoptotic nuclei with the heavy, deuterated $\left(d_{4}\right)$ form. Equal amounts of each reaction were combined and the mixed sample separated by 2-DE. After spot excision, proteins were digested ingel with trypsin and the resulting material subjected to mass spectrometric analysis (MALDI-TOF/TOF). Protein identification was performed by screening against the Swiss-Prot database.

(Fig. 2B). zVAD-fmk efficiently blocked the appearance of apoptotic signaling intermediates and cell death, confirming the caspase-dependency of this pathway.

We then verified the ability of extracts isolated at different time points from CD95-L stimulation to induce distinct stages of apoptosis in isolated liver nuclei by immunoblot analysis of two classical caspase targets, PARP-1 and lamin B 


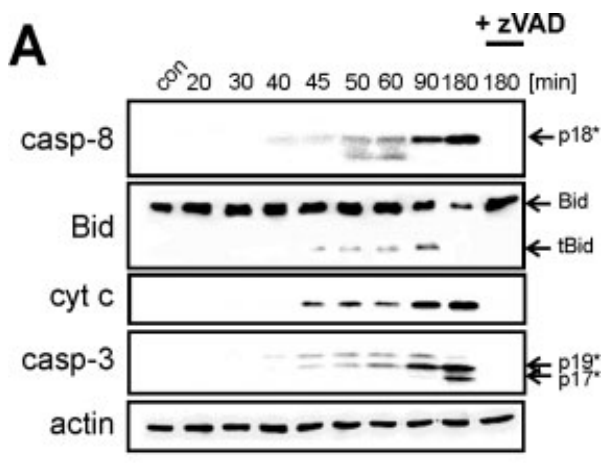

B

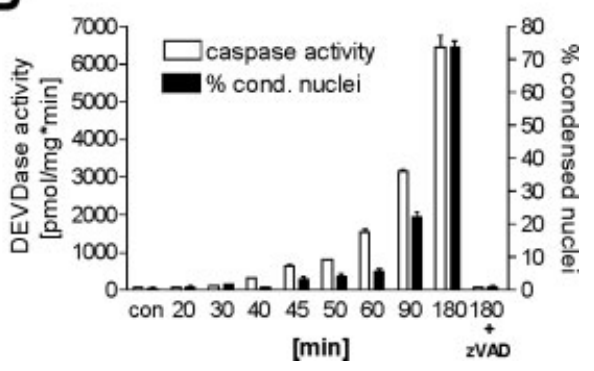

Figure 2. Time-dependent analysis of CD95-L-induced apoptosis in Jurkat cells. (A) Immunoblot analysis of signaling intermediates. The caspase- 3 , caspase- 8 , Bid, and actin blots were performed with whole cell extracts prepared at the indicated time points from either untreated or CD95-L treated Jurkat cells. The cytochrome $c$ blot was performed with lysates obtained from the same cultures after mild digitonin lysis (see Section 2). To inhibit caspases, zVAD-fmk was applied at $20 \mu \mathrm{M}, 30 \mathrm{~min}$ prior to addition of CD95-L. p18: active subunit of caspase-8, p17/p19: large fragment of activated caspase-3, tBid: truncated Bid. (B) Measurement of nuclear condensation and caspase activity in CD95-L treated Jurkat cell cultures. At the indicated time points, cells were stained with Hoechst 33342 and examined at the fluorescence microscope. For each data point $>100$ cells were scored in at least three different microscopic fields. Caspase-3/7-like activity was determined fluorimetrically by DEVD-afc cleavage. The data are representative of at least three independent experiments.

(Fig. 3A), by DNA fragmentation analysis (Fig. 3B), and by microscopic inspection of chromatin structure (Fig. 3C). The characteristic apoptotic signature fragments of PARP-1 $(89 \mathrm{kDa})$ and lamin B $(46 \mathrm{kDa})$ were barely visible after incubation of the nuclei with extracts obtained at $60 \mathrm{~min}$ from initial stimulation (Fig. 3A), when active caspases were present at a low level and only a small fraction $(20 \%)$ of the population displayed condensed nuclei (Fig. 2A and B). Neither oligonucleosomal fragmentation nor gross alteration of chromatin structure were detected in these nuclei (Fig. 3B and C). By contrast, 120 min-extracts induced substantial PARP-1 and lamin B cleavage as well as oligonucleosomal laddering (Fig. 3A and B), consistent with the activation of apoptotic endonucleases downstream of caspases in the CD95-mediated apoptosis pathway. Microscopic analysis of
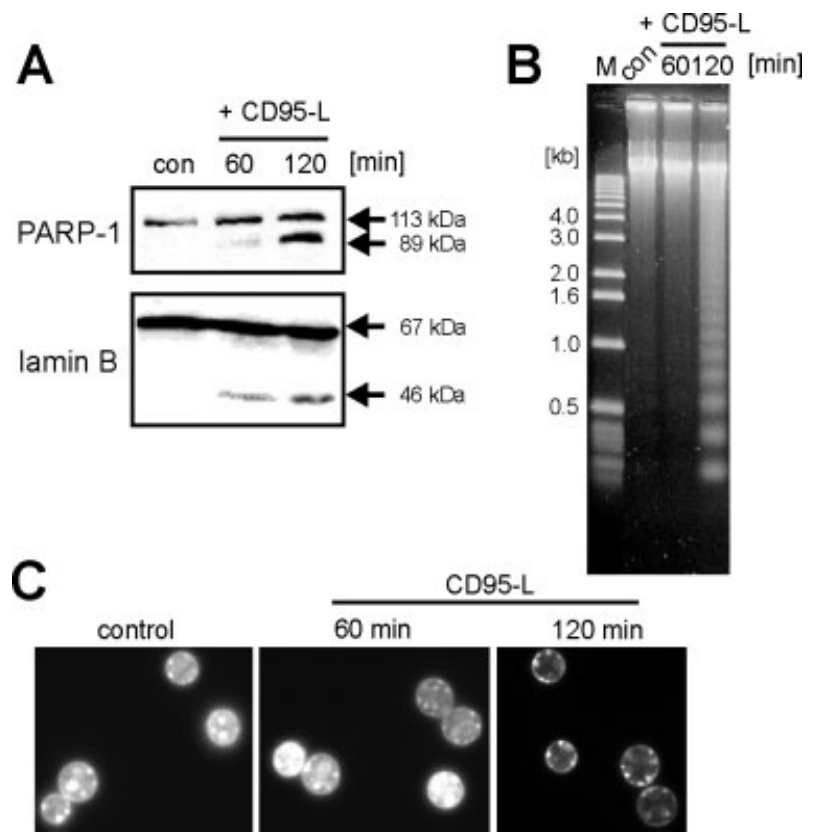

$120 \mathrm{~min}$

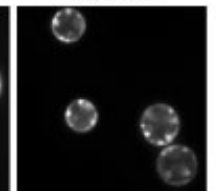

Figure 3. Isolated liver nuclei undergo apoptosis in vitro. (A) Immunoblot analysis of PARP-1 and lamin B cleavage in nuclei exposed to cytosolic extracts derived from either untreated (con) or CD95-L treated Jurkat cells. Extracts were isolated after 60 and $120 \mathrm{~min}$ from initial stimulation. (B) Agarose gel electrophoresis of oligonucleosomal DNA isolated from nuclei treated as in A. (C) Fluorescence microscopic images of nuclei stained with Hoechst 33342 after recovery from cell-free reactions performed as described in A (exposure time $10 \mathrm{~ms}$, magnification $63 \times$ ).

these samples revealed loss of chromatin and nucleolar structures, as well as the induction of peripheral chromatin condensation (Fig. 3C).

These data demonstrate on the one hand, that the in vitro system employed here correctly recapitulates the major features of nuclear apoptosis. On the other hand, they show that the system can be exploited to obtain nuclei arrested at distinct apoptotic stages. Importantly, we did not observe an increase in caspase activity in the isolated extracts during cell-free incubations (data not shown) as could potentially occurr by spontaneous formation of the apoptosome, a caspase-activating multimeric complex [39]. This is most likely due to the high osmolarity of the buffers used for cell extraction and for cell-free incubations $\left(110 \mathrm{mM} \mathrm{K}^{+}\right.$and $70-80 \mathrm{mM}$ $\mathrm{K}^{+}$, respectively) which was shown to efficiently inhibit apoptosome formation [40, 41].

Since we were interested in early apoptotic alterations of the nuclear proteome we wished to isolate cytosolic extracts from cells committed to, but not yet fully engaged in apoptotic execution. For the subsequent experiments we therefore prepared extracts at 30 and $60 \mathrm{~min}$ after CD95-L treatment. The first time point $(30 \mathrm{~min})$ was precedent to caspase activation and apoptotic cell death, whereas at $60 \mathrm{~min}$ a minor fraction of the population displayed an apoptotic morphology, as shown above (Fig. 2B). 
Compared to subcellular proteomic approaches based on the biochemical fractionation of cells undergoing apoptosis the combination of cell-free apoptosis and proteomics described here has the following distinguishing features: (i) Subcellular fractionation bears a notoriously high risk of cross-contamination. In apoptotic cells this is aggravated by the generation of reactive oxygen species (ROS) [42] that compromise the stability of intracellular membranes. Therefore, fractionation protocols established for healthy cells may not be suited for cells undergoing apoptosis. Here, isolating nuclei from a healthy tissue prior to apoptosis induction minimizes the risk of contamination of the nuclei with non-nuclear proteins. (ii) The components of the cell-free reaction, nuclei and cytosol, can be easily isolated and stored in large quantities. Therefore, reactions can be repeated from identical starting material keeping variations in sample preparation to a minimum. (iii) Due to the synchronicity of nuclear apoptosis triggered in vitro, homogenous sample material corresponding to different stages of the apoptotic process can be gained using extracts isolated at different time points from stimulation.

Finally, the reconstituted cell-free apoptosis reaction is unlikely to sustain de novo gene expression in the absence of RNAse inhibitors and without the addition of exogenous precursors. Since caspase-mediate protein cleavage is kept at a low level by the choice of cytosolic extracts (see above), alterations of the nuclear proteome in these reactions will occur predominantly by post-translational events, like protein modifications and migration in and out of the nucleus. These events play an important role in the early cytosol to nucleus signaling phase of apoptosis that we wished to characterize [43-45]. The ICPL technology in turn, has been shown to be particularly suited for the detection of different protein isoforms and protein modifications since it provides good sequence coverage and introduces the isotopic label used for quantification at the protein instead of the peptide level, as e.g., in GIST [22, 46]. Other techniques for quantitative protein profiling, like SILAC/2-DE, have also been employed in similar studies with good results [47]. Here, one major advantage was the shift in $\mathrm{pI}$ introduced by the isotopic label, which allowed to analyze basic nuclear proteins in the neutral region of the 2-DE (see Section 1). The $\mathrm{p} I$ of the proteins is preserved also in DIGE, another common quantitative proteomic platform, which in addition may encounter problems in complex protein mixtures when two or more proteins comigrate [48]. Recently, COFRADIC, a peptide-based proteomic approach, has been successfully applied to the characterization of apoptosis-induced protein degradation [49]. While this method proved very powerful for the detection of protein fragmentation in late apoptotic cells, its exclusive detection of N-terminal peptides is not suited for the study of early stages of apoptosis, where the majority of changes are due to PTMs not necessarily located at the N-terminus.
In sum, we present here a novel combination of cell-free apoptosis and the ICPL proteomic platform directed at the specific detection of early events of nuclear apoptosis, as induced by death-receptor stimulation.

\subsection{Proteome analysis of early apoptotic nuclei}

In an initial experiment we first verified whether we would be able to identify ICPL-modified basic nuclear proteins in the neutral region of a 2-Dgel taking histone proteins as an example. Indeed, histone 1.0, which has a calculated $\mathrm{p} I$ value of 10.9 migrated after ICPL-modification below pI 6 (Fig. 4A upper and lower panel).

Since the control and apoptotic sample were mixed prior to 2-DE, each ICPL-labeled peptide appeared in the mass spectrum as a pair of closely spaced peaks corresponding to the $\mathrm{d}_{0}$ (control, light)- and $\mathrm{d}_{4}$ (apoptotic, heavy) isoform of the reagent. The mass difference between these peaks amounted to $4 \mathrm{Da}$ or a multiple of $4 \mathrm{Da}$ depending on the number of ICPL-modified residues present in the peptide sequence.

This is demonstrated for the RNA-binding protein hnRNP C in Fig. 4B. Changes in protein abundance due to the exposure to apoptotic extracts are expressed as the ratio of the peak intensities in each doublet. In this case, a $60 \%$ decrease in protein level (ratio $\mathrm{d}_{0}: \mathrm{d}_{4}=1: 0.44$ ) was detected in nuclei treated with a 60 min-extract (Fig. 4B, lower panel), while no significant change was visible when the $30 \mathrm{~min}$ extract was used (ratio $d_{0}: d_{4}=1: 1.01$, Fig. $4 B$, upper panel). Peptides showing a change in peak intensities were subjected to MALDI-TOF/TOF for protein identification (Fig. 4C).

The procedure of cell-free apoptosis/proteomic analysis described in Fig. 1 was performed three times using different preparations of extracts and nuclei. In total, 40 proteins were found to be differentially regulated (Supplementary Table 1). Two of them were detected only in nuclei exposed to 30 min-extracts, 25 only in nuclei treated with 60 minextracts, and 13 in both type of samples. Two major classes of proteins emerged from this analysis: chromatin-binding and RNA-processing factors. The first group included several histones, the high-mobility group proteins HMGB1 and B2, the hepatocellular carcinoma protein Hcc-1, heterochromatin-binding protein $1 \gamma(\mathrm{HPl} \gamma)$, and the architectural chromatin factor DEK. RNA-binding proteins comprised hnRNPs and splicing factors like U2 snRNPA', snRNP core $\mathrm{smx} 5, \mathrm{ASF} / \mathrm{SF} 2$, and a protein similar to the splicing factor arginine/serine-rich $(35 \mathrm{kDa})$. Five candidates, i.e., DEK, SnRNP A', snRNP core $\mathrm{smx} 5$, ribosomal protein $\mathrm{S} 7$, and DEAD-box protein 48 ( $\mathrm{Ddx} 48$ ) have not been implicated in cell death so far and thus represent potential novel mediators of nuclear apoptosis.

With few exceptions all proteins were found to be of murine origin (see Supplementary Table 1) indicating that nuclei and cytosol could be efficiently separated after the cellfree reaction and that carry-over of cytosolic components was minimal. The only human proteins detected were: hnRNP 
A
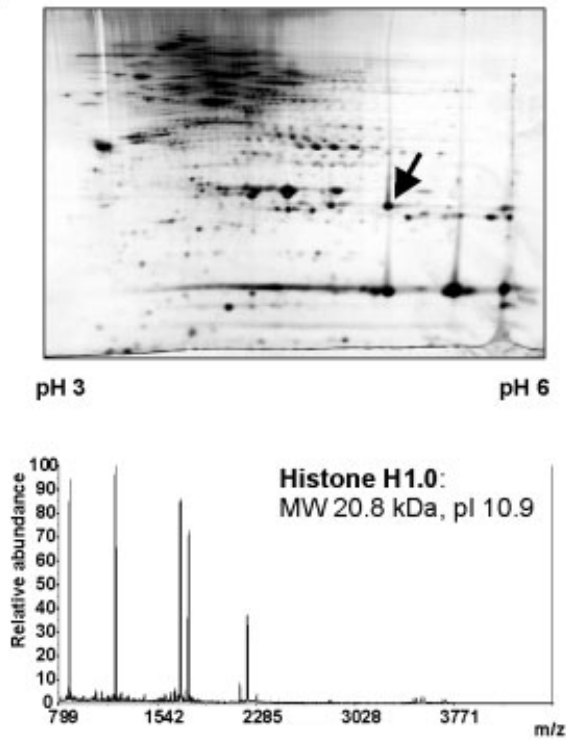

B $30 \mathrm{~min}$ - extract

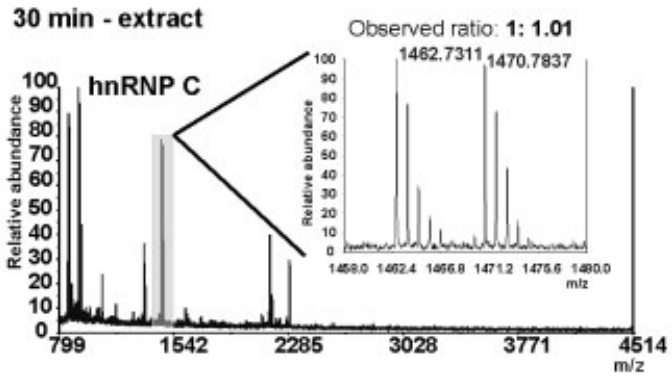

60 min - extract Observed ratio: 1: $\mathbf{0 . 4 4}$

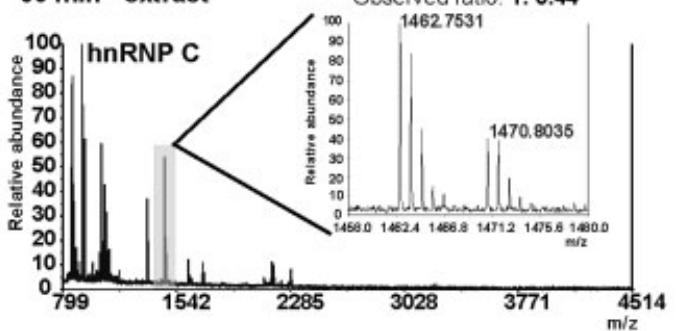

C

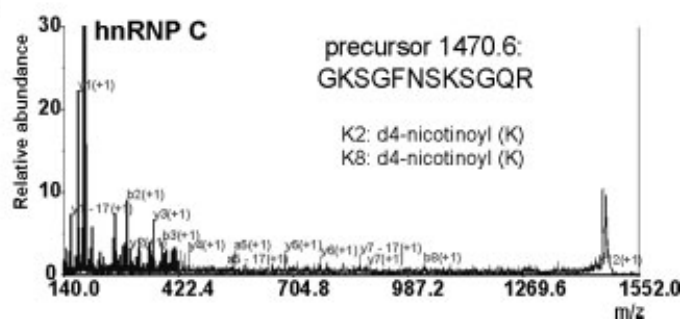

Figure 4. Alterations of basic nuclear proteins are detected in the neutral/acidic region of 2-DE after ICPL-modification. (A) 2-DE analysis of ICPL-modified control nuclei. Nuclei recovered from a cell-free incubation with cytosolic extract from untreated Jurkat cells were chemically derivatized with the nondeuterated $d_{0}$ form of the ICPL reagent. Approximately $1 \mathrm{mg}$ of protein was subjected to IEF on pH 3-6 IPG strips followed by SDS-PAGE as described in Section 2. Protein spots were visualized by silver staining. The arrow indicates the position of histone $\mathrm{H}$ 1.0. The lower panel shows the MALDI-TOF spectrum derived from the indicated spot. (B) MALDI-TOF spectra of a protein spot containing hnRNP C. The experiment was performed as depicted in Fig. 1. Mouse liver nuclei were incubated with cytosolic extracts from untreated Jurkat cells and from cells that had been treated either for $30 \mathrm{~min}$ or $60 \mathrm{~min}$ with CD95-L. After cell-free incubations the nuclei were mixed in equal amounts. The insets show a blow up of one peak in the region between 1458 and $1480 \mathrm{~m} / \mathrm{z}$ revealing a doublet of peptides derivatized either with the $d_{0}$, nondeuterated or the $d_{4}$, deuterated form of the ICPL tag. The control samples were labeled with the $d_{0}$ form, the apoptotic samples with the $d_{4}$ form of ICPL. The mass difference of 8 between the two peaks indicates that the peptide contains two ICPL tags. The ratio of the peak intensities $\left(d_{0}: d_{4}\right)$ is unchanged when the control sample was mixed with the 30 min-sample and is reduced by approximately $60 \%$ when the 60 min-extract was used, indicating a reduction in the level of hnRNPC in this sample. (C) MALDITOF/TOF spectrum of the peptide shown B confirms the presence of two lysines modified with the ICPL tag.

H' and K, Ran, peroxiredoxin I, and ubiquitin. Different mechanisms and observations may account for this: hnRNP H', hnRNP K, and Ran bear nuclear localization sequences which may support their nuclear entry (see e.g. [50, 51]). Peroxiredoxin I/thioredoxin peroxidase- 2 is typically located in the cytosol, but has been recently detected also in the nucleus of lung cancer cells [52]. Human ubiquitin and the mouse Ubc protein, the latter identical to polyubiquitin, were recovered from protein spots migrating in the 2-DE between $M_{\mathrm{r}} 15$ and $20 \mathrm{kDa}$. These most likely represent proteins which are modified with human ubiquitin during the cell-free incubation.
The majority of the identified proteins migrated in the 2-DE as closely spaced spots (Fig. 5). Their position was mostly shifted only in the horizontal dimension reflecting the presence of different species of the same protein differing in $\mathrm{p} I$ but not in molecular weight. Some of the neighboring spots also showed a reciprocal change in the abundance of the corresponding peptide, possibly indicating conversion of one protein species into another (see scatter plots for DEK, Hcc1, and histone H1.0 in Fig. 5). In general the ratio of isotopically light and heavy labeled peptides was moderate compared to those achieved by changes in gene expression 


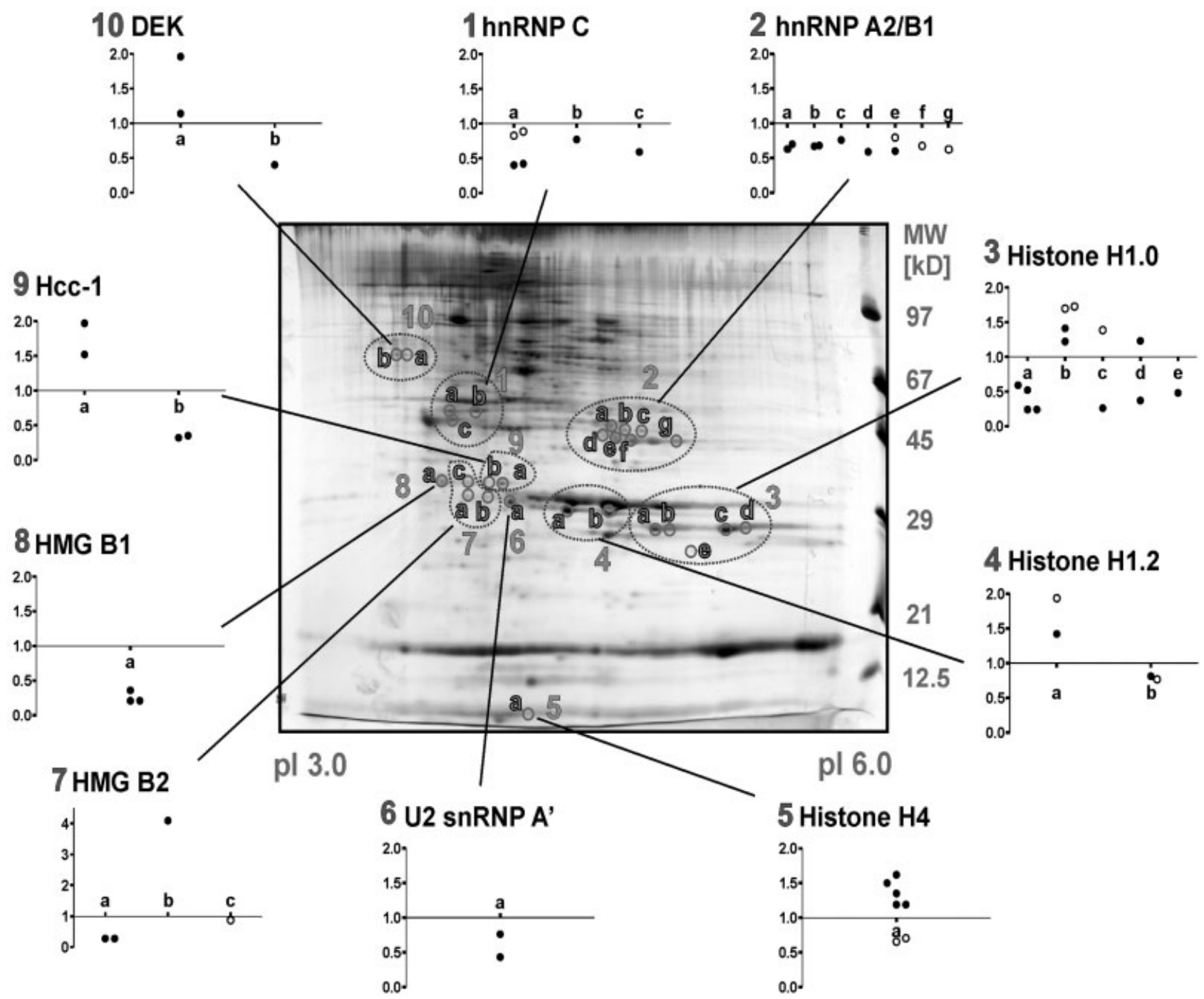

Figure 5. Chromatin- and RNA-binding proteins are altered in CD95-mediated apoptosis in vitro. 2-DE analysis of a mixture of control and apoptotic nuclei labeled with ICPL. Nuclei retrieved from cell-free reactions with cytosolic extracts from untreated and CD95-L treated Jurkat cells were chemically derivatized with the nondeuterated $d_{0}$ and deuterated $d_{4}$ form of the ICPL reagent, respectively. Approximately $1 \mathrm{mg}$ of protein was subjected to IEF on pH 3-6 IPG strips followed by SDS-PAGE as described in Section 2. Protein spots were visualized by silver staining and are marked here by lower case letters (a, b, c, etc.). Spots belonging to the same protein, each spot representing a different isoform or modification are encircled by dotted lines. The Figure highlights the staining pattern of 10 out of 40 nuclear proteins identified as altered during apoptosis. MS-analysis of the spots was performed as exemplified in Fig.4. The results of the MS-analysis are shown in the scatter plots. Each circle represents the $d_{0}: d_{4}$ (control:apoptotic) ratio for one protein species as determined in the respective spot and listed in Supplementary Table 1. Multiple circles belonging to the same spot indicate results obtained from independent 2-D analyses. Data obtained from experiments performed with 60 min-extracts are indicated by closed circles, open circles show results from 30 min-reactions. Values $>1$ indicate an increase of the respective protein species in apoptotic nuclei as compared to control nuclei.

[53]. These values, which indicate the relative factor of decrease or increase of the corresponding proteins in the apoptotic sample as compared to control, ranged from 0.28 to 1.96 (see Supplementary Table 1). Collectively these observations corroborate our assumption that nuclear protein alterations in the cell-free apoptosis reaction are mainly arising from post-translational processes rather than from de novo gene expression.

\subsection{Chromatin-binding proteins in nuclear apoptosis}

Histone modifications are known to modulate chromatin architecture and function, and have been associated with apoptosis both by proteomic and nonproteomic studies (see Supplementary Table 1). Modifications that have been observed in different model systems of cellular damage include dephosphorylation of $\mathrm{H} 1$ family histones [54], de- 
ubiquitination of H2A [55], poly(ADP-ribosyl)ation of H1 [56], biotinylation of $\mathrm{H} 1, \mathrm{H} 2 \mathrm{~A}, \mathrm{H} 2 \mathrm{~B}, \mathrm{H} 3$, and $\mathrm{H} 4$ [57], hypoacetylation of $\mathrm{H} 4$ [58], and phosphorylation of $\mathrm{H} 2 \mathrm{~B}$ [59]. In the present study, we have identified H1.4 as a further potential target for apoptosis-specific modification. In general these modifications are believed to increase the accessibility of chromatin for apoptotic endonucleases favoring chromatin condensation, although the exact mechanisms linking histone modification to these processes are not yet understood [60]. Histones may eventually separate from chromatin and be released from the nucleus and/or be exposed at the cell surface as potent autoantigens [61, 62]. In irradiated cells nuclear release of $\mathrm{H} 1.2$ has been shown to function as apoptotic signal directed at the mitochondria [63].

High-mobility group proteins are DNA-binding factors affecting chromatin architecture and act in concert with histones in regulating chromatin function [64]. Similarly to histones, their PTMs, in particular methylation, dephosphorylation, and poly(ADP-ribosyl)ation have been associated with apoptosis [65-67]. HMGB2 has further been shown to activate the apoptotic endonuclease DFF40 in vitro [68]. To our knowledge, the present study provides the first proteomic data supporting an involvement of HMGB2 in apoptosis. The distribution pattern of HMGB2-specific signals on the 2-DE shows three closely spaced spots, suggestive of PTMs. Whether these modifications are involved in the ability of HMGB2 to activate DFF40 remains an open question.

Hcc-1 is a component of the nuclear matrix that is upregulated in a number of tumors and possesses a conserved $\mathrm{N}$ terminal DNA-binding SAP (SAF A/B, Acinus, Pias) domain $[69,70]$. When expressed in mammalian cells, Hcc-1 exerts an antiproliferative effect that has been attributed to cell cycle arrest at the G2/M boundary and more recently to induction of apoptosis [70]. Interestingly, Hcc-1 has been reported to interact with two DEAD-box proteins, Bat1 and Ddx39 [70]. These are members of a broad family of RNA-binding ATPases with helicase activity that are involved in virtually all cellular processes requiring manipulation of RNA structure [71]. One member of this family, Ddx48, that has not been involved in apoptosis so far, has been identified also in our proteomic screen (Supplementary Table 1).

A further candidate mediator of nuclear apoptosis that emerged from this study is HP1 $\gamma$. HP1 is a chromatinbinding protein that occurs in three isoforms $\alpha, \beta$, and $\gamma$, and plays a major role in the maintenance and inheritance of pericentric heterochromatin (reviewed in [72]). All three isoforms have been shown to interact with histones, in particular with histone H3 [73]. This interaction is strongly affected by post-translational histone modification and was proposed to mediate binding of HP1 to lamin B receptor (LBR), a component of the nuclear envelope, providing a mechanism for the tethering of HP1-enriched heterochromatic domains to the nuclear envelope [74].

Finally, we identified DEK, a chromatin bound nuclear phosphoprotein that does not belong to any known protein family and has not been associated with apoptosis so far. The only recognizable functional domain is a SAP-box. Proteins containing this DNA-binding motif participate in chromatin organization, mRNA processing and transcription, and DEK was implicated in all these processes (reviewed in [28]). Despite these findings the function of DEK remains unclear.

In summary, using an in vitro assay consisting of nuclei from healthy tissue and early-phase apoptotic extracts we have identified histones, HMGs and a few other architectural chromatin proteins, including DEK, as potentially involved in nuclear apoptosis. These results point to the fact that signals affecting the topological organization of chromatin are directed to the nucleus already at an early stage of death-receptor triggered apoptosis, preceding the substantial activation of executor caspases and of DNA cleaving enzymes. This may represent a general feature of the commitment phase of apoptotic cell death. In line with these conclusions, Kroemer and coworkers have shown that a short pulse of staurosporine, an efficient inducer of apoptosis, induces in moderate alterations of chromatin morphology that do not necessarily result in cell death. This preapoptotic status was termed PACC, for preapoptotic chromatin condensation. PACC occurred independently of executor caspases and was not associated with oligonucleosomal DNA fragmentation [75].

\subsection{RNA-processing factors involved in nuclear apoptosis}

Rearrangements of ribonucleoprotein-containing compartments leading to the formation of aggregates termed HERDS (heterogenous ectopic RNP-derived structures) have been detected during apoptosis by electron microscopy studies and were shown to accompany the typical apoptotic changes of chromatin structure [76-78]. Among the RNPs identified in HERDS are pre-mRNA-binding RNPs, hnRNPs, and small nuclear RNPs, snRNPs, as well as other, non-snRNP splicing factors [77]. In addition to these morphological data, alterations of hnRNPs have been reported also by proteome studies in different models of cell death (see Supplementary Table 1). HnRNPA2/B1, a shuttling hnRNP, was found to accumulate in the cytoplasm of CD95L treated Jurkat cells [18], corroborating our own results which show a consistent reduction of the hnRNPA2/B1 level in nuclei incubated with apoptotic cytosol (Fig. 5). This effect is among the few ones that we repeatedly observed in nuclei incubated with 30 min-extracts, i.e., in absence of active caspases, suggesting that alterations of hnRNPA2/B1 trafficking is among the very early nuclear events in CD95-Linduced apoptosis. We also detected a decrease of nuclear levels of hnRNP C1/C2, a nonshuttling hnRNP [79]. This hnRNP has been identified early on as a caspase substrate [80]. Proteolytic cleavage may partly account for the loss of hnRNP C1/C2 from liver nuclei in the cell-free apoptosis reaction, but is not likely to play a major role, given the low level of active caspases in this system. More importantly, a caspase-independent mechanism of nuclear efflux of hnRNP $\mathrm{C} 1 / \mathrm{C} 2$ has been recently described which does not involve 
proteolytic cleavage but the activation of a novel nuclear export signal located at the C-terminus of the protein by Rhoassociated kinase [81].

Our study further revealed a reduction in the level of hnRNP H', hnRNP K, and hnRNP I. Little is known about the physiological significance of the involvement of hnRNPs in apoptosis. hnRNP F and $\mathrm{H}$ have been shown to modulate the alternative splicing of Bcl-x pre-mRNA [82] and several hnRNPs have been identified in proteomic studies of apoptotic cells (see Supplementary Table 1). This supports the assumption that alterations of hnRNP nucleo-cytoplasmic distribution and/or their PTMs may indeed have a functional significance in apoptosis.

Among the RNPs identified in this study are also splicing factors like the snRNP core protein Smx5, the U2 snRNP A'and ASF/SF2. While the molecular alterations occurring in this system remain to be determined, it is known from literature that modification of splicing factors by phosphorylation regulate protein-protein and protein-RNA interactions within the spliceosome. This may influence the progression of the splicing reaction and the choice of the splice-site in alternative splicing (reviewed in [83]). The induction of changes in the levels of specific splicing factors during exposure of nuclei to apoptotic extracts may reflect an early reprogramming of splicing reactions as part of the commitment phase of apoptosis. In fact, many members of the apoptosis pathway were shown to be regulated by alternative splicing. These include the genes encoding Bcl-2 family members, several caspases, Apaf-1, the endonuclease DFF40/CAD, and CD95 (reviewed in [84]).

Finally, our data point to an early involvement of the nucleolus in the CD95-dependent signal pathway. Two components of the $40 \mathrm{~S}$ ribosomal subunit were found to be altered in preapoptotic nuclei, S3A and S7. Also nucleophosmin, an abundant nucleolar phosphoprotein involved in ribosomal biogenesis was identified as a target of CD95induced apoptosis. Several lines of evidence support a role of nucleophosmin as an antiapoptotic survival protein $[85,86]$. More recently, nucleophosmin has been shown to mediate the antiapoptotic effects of NGF by binding and inhibiting the apoptotic DNAse DFF40/CAD in the presence of phosphatidylinositol 3,4,5-triphosphate [87]. This function of nucleophosmin was proposed to be regulated by PTM, in particular by phosphorylation. The identification of nucleophosmin in our study suggests that the regulation of the nucleophosmin-CAD interaction by phosphorylation may represent also a novel regulatory component of death receptor-mediated apoptosis.

\subsection{DEK is hypophosphorylated in apoptotic nuclei}

One of the proteins identified in this study for which a link to apoptosis had not been established so far is the chromatin architectural factor DEK. The DEK protein was initially identified as an oncogenic fusion with the nucleoporin CAN/ Nup214 in patients suffering from acute myeloid leukemia
[88]. An increased level of DEK mRNA in many cancerous cells has been reported suggesting that DEK may play a role in cellular transformation and senescence [89-95]. In addition, DEK has been shown to be a major antigen in several autoimmune disorders [96]. However, the biological function of DEK and the molecular mechanisms by which it contributes to disease pathogenesis have not been clarified yet.

DEK is an abundant nuclear phosphoprotein [97] that is tightly associated with chromatin throughout the cell cycle [98]. In vitro, DEK was shown to modify chromatin topology by introducing constrained positive supercoils in closed circular DNA templates, an activity which requires topoisomerase I [99, 100]. The structural features of DEK have been reviewed recently and a model for the interaction of DEK with DNA has been proposed [28]. This model takes into account the observation that DEK's binding to DNA as well as its ability to form multimers are modulated by phosphorylation, mainly by the protein kinase CK2. Increasing the level of phosphorylation reduces the affinity of DEK for DNA and augments its tendency to form aggregates [36, 101].

In the 2-DE of the ICPL-labeled nuclear samples DEK was identified in two protein spots migrating at slightly different $\mathrm{p} I$ - but identical $M_{\mathrm{r}}$-values, which was indicative of the occurrence of two differentially modified species of the protein. The determination of the ratio of light $\left(\mathrm{d}_{0}\right.$, control) to heavy $\left(\mathrm{d}_{4}\right.$, apoptotic) isomer in both spots showed that in the apoptotic sample the more basic DEK-variant (spot a) was increased, while the more acidic (spot b) was decreased (Fig. 6A). Considering that DEK is a known target for phosphorylation in vivo and in vitro, these data potentially indicated a change in the phosphorylation status of DEK in liver nuclei during the cell-free apoptosis reaction. To confirm this we compared the ability of extracts gained from untreated and apoptotic Jurkat cells to phosphorylate recombinant Histagged DEK under conditions identical to those employed for the cell-free apoptosis reaction. As shown in Fig. 6B extracts from healthy Jurkat cells induced a robust phosphorylation of DEK in vitro, in accordance to previous results with HeLa cell extracts [36]. A progressive decrease in the level of DEK phosphorylation was observed with extracts derived from Jurkat cells treated for different times with CD95-L, in line with our results from the proteome analysis of liver nuclei. Since this experiment was performed in the presence of phosphatase inhibitors, the decrease in phosphorylation is most likely due to a reduced kinase activity in the corresponding extracts and not to the induction of a DEK-specific phosphatase in the course of apoptosis. Finally, we were interested to determine whether a change in the level of DEK phosphorylation would also occur in intact cells undergoing apoptosis. For this purpose Jurkat cells were labeled with ${ }^{32} \mathrm{P}$ orthophosphate and incubated for different times in the presence or absence of CD95-L. Cleavage of PARP-1 occurred specifically and in a time-dependent manner in the CD95-L treated cultures as shown by immunoblot analysis (Fig. 6C). No degradation of DEK could be detected in these cultures (Fig. 6C). Autoradiography of immunoprecipitated 
A

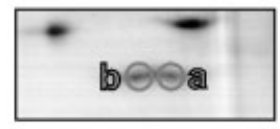

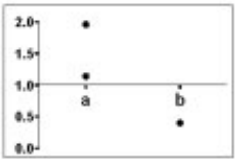
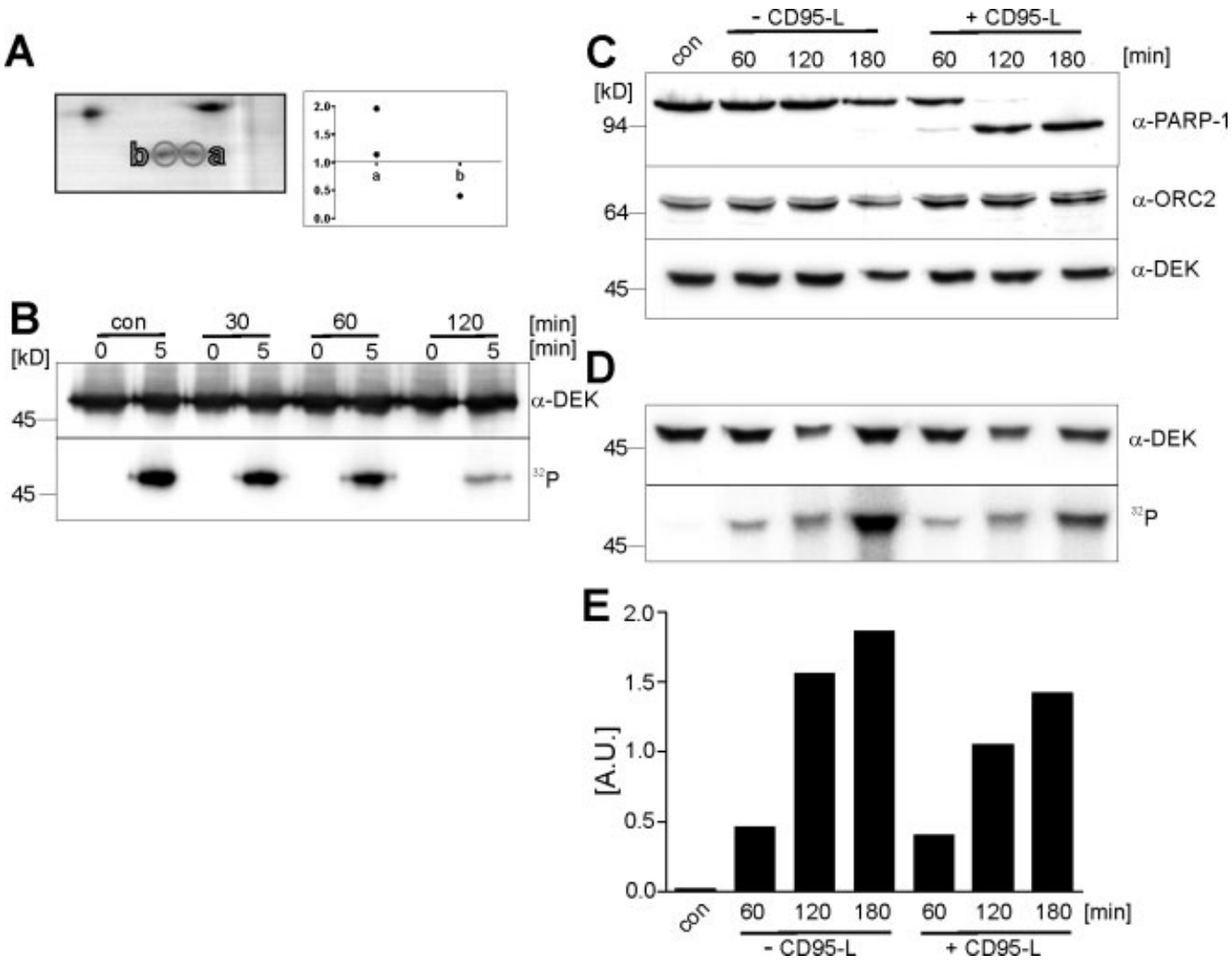

Figure 6. DEK is hypophosphorylated in apoptosis in vitro and in vivo. (A) zoomed area of the 2-D gel of Fig. 5 highlighting the DEK-specific spots. The scatter plot shows the results of the quantitation as described in the legend to Fig. 5 and Section 2. In the apoptotic sample the DEK-specific signal from spot (a) is increased, while spot (b) decreases, suggesting a PTM of the protein. (B) In vitro phosphorylation. Recombinant, dephosphorylated His-tagged DEK $(500 \mathrm{ng})$ was incubated with equal amounts (150 $\mu \mathrm{g}$ total protein) of S-20 extract, obtained from untreated (con) or from Jurkat cells treated for the indicated time points with CD95-L (30, 60, and 120 min) and in the presence of $\gamma_{-}{ }^{32}$ P-ATP. Reactions were stopped immediately $(0 \mathrm{~min})$ or after $5 \mathrm{~min}$, and DEK was purified using Ni-NTA-agarose. The individual eluates were analyzed by immunoblotting ( $\alpha$-DEK) and autoradiography $\left({ }^{32} \mathrm{P}\right)$. (C) In vivo labeling of control and CD95-L treated Jurkat cells. Jurkat cells were collected and incubated in the presence of ${ }^{32} \mathrm{Pi}$ either with or without $2.5 \%$ of CD95-L. At the indicated time points a total cell lysate was produced and analyzed in immunoblots with PARP-1, ORC-2 and DEK specific antibodies. (D) The same extracts were treated with polyclonal DEK specific antibodies and the eluted immunocomplexes were analyzed by autoradiography $\left({ }^{32} \mathrm{P}\right)$ and immunoblotting with a monoclonal DEK antibody ( $\alpha$-DEK, BD Bioscience). (E) For densitometric analysis, bands were scanned and analyzed by NIH Imager. The ratio of the autoradiograph versus the immunoblot is visualized.

DEK from the same experiment as in Fig. 6C indicated a lower level of DEK phosphorylation in the lysates obtained from cells undergoing apoptosis as compared to control lysates (compare immunoblot signals with autoradiography, Fig. 6E). This appeared most clearly at $3 \mathrm{~h}$ after treatment (Fig. 6D and E, compare lane 4 with lane 7). ORC-2, a component of the origin recognition complex, was unaffected in this experiment and served as a loading control (Fig. 6C).

At present, the significance of DEK hypophosphorylation in apoptosis is unclear. A lower level of DEK phosphorylation however, is expected to enhance its DNA binding activity. This in turn may contribute to keep DEK fixed to chromatin during the process of nuclear destruction and apoptotic body formation avoiding a potentially harmful release of the protein to the cytoplasm and the extracellular space. Failure of the nuclear retention of DEK may be relevant for its role as autoantigen. A similar scenario has been shown to apply for HMGB1, which can act as a potent proinflammatory stimulus when released by necrotic cells. In apoptotic cells, HMGB1 is irreversibly locked to chromatin as a consequence of histone hypoacetylation [58]. As a further possibility, hypophosphorylated DEK may facilitate chromatin compaction by bridging between distant binding sites on the same or on different DNA strands via its two DNA-binding domains, as proposed by the model of Waldmann et al. [28]. Third, DEK hypophosphorylation in apoptosis may impinge on its postulated functions in splicing and transcription. In fact, dephosphorylation of DEK has been shown to relieve transcriptional repression of the human immunodeficiency Virus type 2 (HIV-2) promoter [102] in mitogenically stimulated leukemia cells. 
In summary we have shown that the DEK protein is hypophosphorylated in apoptosis induced in vitro and in vivo. This validates our results from the proteomic analysis of nuclear apoptosis and highlights the potential of this approach for the investigation of apoptosis-induced PTMs. Furthermore, our results establish a previously unrecognized link between DEK and cell death, which will prove useful in the search for the physiological function of this protein.

\section{Concluding remarks}

Cell death by apoptosis is characterized by dramatic alterations of nuclear morphology and chromatin architecture. These are brought about mainly by the action of the caspase family of proteases, by apoptosis-specific endonucleases, and chromatin condensation factors. We have performed a proteomic screen of apoptotic nuclei using a combination of cell-free apoptosis and ICPL. Interestingly, part of the proteins identified in this study have emerged also from previous proteomic studies of apoptotic cells using different apoptotic stimuli, fractionation techniques, and proteomic platforms (for a complete reference list, see Supplementary Table 1). While, on the one hand, this corroborates the significance of our data, on the other hand it shows that different strategies of proteomic analysis, each bearing different merits and disadvantages, may complement each other and collectively contribute to characterize apoptosis-induced alterations of the cellular proteome (see e.g. [48]). Since ICPL is a rather new platform, only very few reports using this technique are available at present. More studies are to be awaited in the future and will allow for accurate crosscomparison of this method with other quantitative protein profiling tools.

The study described here was aimed specifically at displaying changes of the protein complement of the nucleus triggered at an early phase of cell death. The identification of chromatin architectural proteins and RNA-processing factors in our screen suggests that initial steps of apoptotic signaling may occur in the nucleus prior to the full activation of the cytoplasmic caspase cascade. These steps may involve PTMs of nuclear proteins, as exemplified for the protein DEK. Assessing the role of the identified candidates and particularly of the hypophosphorylation of DEK, in the process of apoptotic cell death is a challenging endeavor for the future.

We gratefully acknowledge Daniela Hermann for expert technical assistance, Alexander Schmidt for help with ICPLlabeling, Monika Zobawa for mass spectrometry, Volker Cordes for help with the isolation of mice liver nuclei, U. Brandes for advice on data representation, Johannes Beckers for $\mathrm{C} 3 \mathrm{HeB} / \mathrm{FeJ}$ mice, and A. Bürkle for $\alpha$-PARP-1 antibodies. This work was supported by grants to E. Ferrando-May and J. Kellermann (DFG MA 2385/2-1/2 and KE 875/1-1/2).

\section{References}

[1] Kerr, J. F., Wyllie, A. H., Currie, A. R., Br. J. Cancer 1972, 26, 239-257.

[2] Wyllie, A. H., Beattie, G. J., Hargreaves, A. D., Histochem. J. 1981, 13, 681-692.

[3] Oberhammer, F. A., Hochegger, K., Fröschl, G., Tiefenbacher, R., Pavelka, M., J. Cell Biol. 1994, 126, 827-837.

[4] Ferrando-May, E., Cordes, V., Biller, I., Görlich, D. et al., Cell Death Differ. 2001, 8, 495-505.

[5] Enari, M., Sakahira, H., Yokoyama, H., Okawa, K. et al., Nature 1998, 391, 43-50.

[6] Liu, X., Zou, H., Slaughter, C., Wang, X., Cell 1997, 89, 175184

[7] Degterev, A., Boyce, M., Yuan, J., Oncogene 2003, 22, 85438567.

[8] Susin, S. A., Lorenzo, H. K., Zamzami, N., Marzo, I. et al., Nature 1999, 397, 441-446.

[9] Li, L. Y., Luo, X., Wang, X., Nature 2001, 412, 95-99.

[10] Mcllroy, D., Tanaka, M., Sakahira, H., Fukuyama, H. et al., Genes Dev. 2000, 14, 549-558.

[11] Shinzawa, K., Tsujimoto, Y., J. Cell Biol. 2003, 163, 12191230.

[12] Sahara, S., Aoto, M., Eguchi, Y., Imamoto, N. et al., Nature $1999,401,168-173$.

[13] Hall, J. C., Casciola-Rosen, L., Rosen, A., Rheum. Dis. Clin. North Am. 2004, 30, 455-471 (vii).

[14] Cline, A. M., Radic, M. Z., Clin. Immunol. 2004, 112, 175-182.

[15] Doyle, H. A., Mamula, M. J., Ann. NY Acad. Sci. 2005, 1050, 1-9.

[16] Dreger, M., Mass Spectrom. Rev. 2003, 22, 27-56.

[17] Gygi, S. P., Corthals, G. L., Zhang, Y., Rochon, Y., Aebersold, R., Proc. Natl. Acad. Sci. USA 2000, 97, 9390-9395.

[18] Thiede, B., Siejak, F., Dimmler, C., Rudel, T., Proteomics 2002, 2, 996-1006.

[19] Machuy, N., Thiede, B., Rajalingam, K., Dimmler, C. et al., Mol. Cell. Proteomics 2005, 4, 44-55.

[20] Gerner, C., Gotzmann, J., Frohwein, U., Schamberger, C. et al., Cell Death Differ. 2002, 9, 671-681.

[21] Görg, A., Obermaier, C., Boguth, G., Harder, A. et al., Electrophoresis 2000, 21, 1037-1053.

[22] Schmidt, A., Kellermann, J., Lottspeich, F., Proteomics 2005, 5, 4-15.

[23] Gygi, S. P., Rist, B., Gerber, S. A., Turecek, F. et al., Nat. Biotechnol. 1999, 17, 994-999.

[24] Fearnhead, H. O., Methods Cell Biol. 2001, 66, 167-185.

[25] Lazebnik, Y. A., Cole, S., Cooke, C. A., Nelson, W. G., Earnshaw, W. C., J. Cell Biol. 1993, 123, 7-22.

[26] Martin, S. J., Newmeyer, D. D., Mathias, S., Farschon, D. M. et al., EMBO J. 1995, 14, 5191-5200.

[27] Enari, M., Hase, A., Nagata, S., EMBO J. 1995, 14, 5201-5208.

[28] Waldmann, T., Scholten, I., Kappes, F., Hu, H. G., Knippers, R., Gene 2004, 343, 1-9.

[29] Sitwala, K. V., Mor-Vaknin, N., Markovitz, D. M., Anticancer Res. 2003, 23, 2155-2158.

[30] Rensing-Ehl, A., Frei, K., Flury, R., Matiba, B. et al., Eur. J. Immunol. 1995, 25, 2253-2258. 
[31] Blobel, G., Potter, V. R., Science 1966, 154, 1662-1665.

[32] Cordes, V., Thesis, Ruprecht-Karls-University Heidelberg, 1992.

[33] Single, B., Leist, M., Nicotera, P., Exp. Cell Res. 2001, 262, 816.

[34] Laemmli, U. K., Nature 1970, 227, 680-685.

[35] Perkins, D. N., Pappin, D. J., Creasy, D. M., Cottrell, J. S., Electrophoresis 1999, 20, 3551-3567.

[36] Kappes, F., Damoc, C., Knippers, R., Przybylski, M. et al., Mol. Cell. Biol. 2004, 24, 6011-6020.

[37] Krammer, P. H., Nature 2000, 407, 789-795.

[38] Chow, S. C., Weis, M., Kass, G. E., Holmstrom, T. H. et al., FEBS Lett. 1995, 364, 134-138.

[39] Cain, K., Bratton, S. B., Cohen, G. M., Biochimie 2002, 84, 203-214.

[40] Purring-Koch, C., McLendon, G., Proc. Natl. Acad. Sci. USA 2000, 97, 11928-11931.

[41] Cain, K., Langlais, C., Sun, X. M., Brown, D. G., Cohen, G. M., J. Biol. Chem. 2001, 276, 41985-41990.

[42] Suzuki, Y., Ono, Y., Hirabayashi, Y., FEBS Lett. 1998, 425, 209 212.

[43] Morley, S. J., Coldwell, M. J., Clemens, M. J., Cell Death Differ. 2005, 12, 571-584.

[44] Datta, S. R., Dudek, H., Tao, X., Masters, S. et al., Cell 1997, 91, 231-241.

[45] Ferrando-May, E., Cell Death Differ. 2005, 12, 1263-1276.

[46] Chakraborty, A., Regnier, F. E., J. Chromatogr. A 2002, 949, 173-184.

[47] Thiede, B., Kretschmer, A., Rudel, T., Proteomics 2006, 6, 614-622.

[48] Wu, W. W., Wang, G., Baek, S. J., Shen, R. F., J. Proteome Res. 2006, 5, 651-658.

[49] Van Damme, P., Martens, L., Van Damme, J., Hugelier, K. et al., Nat. Methods 2005, 2, 771-777.

[50] Kim, J. H., Hahm, B., Kim, Y. K., Choi, M., Jang, S. K., J. Mol. Biol. 2000, 298, 395-405.

[51] Dasso, M., Curr. Biol. 2002, 12, R502-R508.

[52] Kinnula, V. L., Lehtonen, S., Sormunen, R., KaarteenahoWiik, R. et al., J. Pathol. 2002, 196, 316-323.

[53] Shiio, Y., Eisenman, R. N., Yi, E. C., Donohoe, S. et al., J. Am. Soc. Mass Spectrom. 2003, 14, 696-703.

[54] Kratzmeier, M., Albig, W., Hanecke, K., Doenecke, D., J. Biol. Chem. 2000, 275, 30478-30486.

[55] Mimnaugh, E. G., Kayastha, G., McGovern, N. B., Hwang, S. G. et al., Cell Death Differ. 2001, 8, 1182-1196.

[56] Yoon, Y. S., Kim, J. W., Kang, K. W., Kim, Y. S. et al., J. Biol. Chem. 1996, 271, 9129-9134.

[57] Peters, D. M., Griffin, J. B., Stanley, J. S., Beck, M. M., Zempleni, J., Am. J. Physiol. Cell Physiol. 2002, 283, C878-C884.

[58] Scaffidi, P., Misteli, T., Bianchi, M. E., Nature 2002, 418, 191195.

[59] Cheung, W. L., Ajiro, K., Samejima, K., Kloc, M. et al., Cell 2003, 113, 507-517.

[60] Th'ng, J. P., Biochem. Cell Biol. 2001, 79, 305-311.

[61] Wu, D., Ingram, A., Lahti, J. H., Mazza, B. et al., J. Biol. Chem. 2002, 277, 12001-12008.
[62] Radic, M., Marion, T., Monestier, M., J. Immunol. 2004, 172, 6692-6700.

[63] Konishi, A., Shimizu, S., Hirota, J., Takao, T. et al., Cell 2003, $114,673-688$.

[64] Catez, F., Yang, H., Tracey, K. J., Reeves, R. et al., Mol. Cell. Biol. 2004, 24, 4321-4328.

[65] Diana, F., Sgarra, R., Manfioletti, G., Rustighi, A. et al., J. Biol. Chem. 2001, 276, 11354-11361.

[66] Sgarra, R., Diana, F., Bellarosa, C., Dekleva, V. et al., Biochemistry 2003, 42, 3575-3585.

[67] Giancotti, V., Bandiera, A., Sindici, C., Perissin, L., CraneRobinson, C., Biochem. J. 1996, 317, 865-870.

[68] Toh, S. Y., Wang, X., Li, P., Biochem. Biophys. Res. Commun. 1998, 250, 598-601.

[69] Choong, M. L., Tan, L. K., Lo, S. L., Ren, E. C. et al., FEBS Lett. 2001, 496, 109-116.

[70] Leaw, C. L., Ren, E. C., Choong, M. L., Cell. Mol. Life Sci 2004, 61, 2264-2273.

[71] Rocak, S., Linder, P., Nat. Rev. Mol. Cell. Biol. 2004, 5, 232241.

[72] Maison, C., Almouzni, G., Nat. Rev. Mol. Cell. Biol. 2004, 5, 296-304.

[73] Nielsen, A. L., Oulad-Abdelghani, M., Ortiz, J. A., Remboutsika, E. et al., Mol. Cell 2001, 7, 729-739.

[74] Polioudaki, H., Kourmouli, N., Drosou, V., Bakou, A. et al., EMBO Rep. 2001, 2, 920-925.

[75] Andreau, K., Castedo, M., Perfettini, J. L., Roumier, T. et al., J. Biol. Chem. 2004, 279, 55937-55945.

[76] Biggiogera, M., Bottone, M. G., Pellicciari, C., Histochem. Cell Biol. 1997, 107, 331-336.

[77] Biggiogera, M., Bottone, M. G., Scovassi, A. I., Soldani, C. et al., Biol. Cell 2004, 96, 603-615.

[78] Biggiogera, M., Bottone, M. G., Pellicciari, C., J. Histochem. Cytochem. 1998, 46, 999-1005.

[79] Pinol-Roma, S., Dreyfuss, G., Nature 1992, 355, 730-732.

[80] Waterhouse, N., Kumar, S., Song, Q., Strike, P. et al., J. Biol. Chem. 1996, 271, 29335-29341.

[81] Lee, H. H., Chien, C. L., Liao, H. K., Chen, Y. J., Chang, Z. F., J. Cell Sci. 2004, 117, 5579-5589.

[82] Garneau, D., Revil, T., Fisette, J. F., Chabot, B., J. Biol. Chem. 2005, 280, 22641-22650.

[83] Misteli, T., Curr. Biol. 1999, 9, R198-200.

[84] Schwerk, C., Schulze-Osthoff, K., Mol. Cell 2005, 19, 1-13.

[85] Li, J., Zhang, X., Sejas, D. P., Bagby, G. C., Pang, Q., J. Biol. Chem. 2004, 279, 41275-41279.

[86] Itahana, K., Bhat, K. P., Jin, A., Itahana, Y. et al., Mol. Cell 2003, 12, 1151-1164.

[87] Ahn, J. Y., Liu, X., Cheng, D., Peng, J. et al., Mol. Cell 2005, $18,435-445$

[88] von Lindern, M., Fornerod, M., van Baal, S., Jaegle, M. et al., Mol. Cell. Biol. 1992, 12, 1687-1697.

[89] Kondoh, N., Wakatsuki, T., Ryo, A., Hada, A. et al., Cancer Res. 1999, 59, 4990-4996.

[90] Savli, H., Aalto, Y., Nagy, B., Knuutila, S., Pakkala, S., Br. J. Haematol. 2002, 118, 1065-1070.

[91] Kroes, R. A., Jastrow, A., McLone, M. G., Yamamoto, H. et al., Cancer Lett. 2000, 156, 191-198. 
[92] Grottke, C., Mantwill, K., Dietel, M., Schadendorf, D., Lage, H., Int. J. Cancer 2000, 88, 535-546.

[93] Larramendy, M. L., Niini, T., Elonen, E., Nagy, B. et al., Haematologica 2002, 87, 569-577.

[94] Orlic, M., Spencer, C. E., Wang, L., Gallie, B. L., Genes Chromosomes Cancer 2006, 45, 72-82.

[95] Wise-Draper, T. M., Allen, H. V., Thobe, M. N., Jones, E. E. et al., J. Virol. 2005, 79, 14309-14317.

[96] Dong, X., Wang, J., Kabir, F. N., Shaw, M. et al., Arthritis Rheum. 2000, 43, 85-93.

[97] Fornerod, M., Boer, J., van Baal, S., Jaeglé, M. et al., Oncogene 1995, 10, 1739-1748.
[98] Kappes, F., Burger, K., Baack, M., Fackelmayer, F. O., Gruss, C., J. Biol. Chem. 2001, 276, 26317-26323.

[99] Alexiadis, V., Waldmann, T., Andersen, J., Mann, M. et al., Genes Dev. 2000, 14, 1308-1312.

[100] Waldmann, T., Eckerich, C., Baack, M., Gruss, C., J. Biol. Chem. 2002, 277, 24988-24994.

[101] Kappes, F., Scholten, I., Richter, N., Gruss, C., Waldmann, T., Mol. Cell. Biol. 2004, 24, 6000-6010.

[102] Faulkner, N. E., Hilfinger, J. M., Markovitz, D. M., J. Biol. Chem. 2001, 276, 25804-25812. 